\title{
The Concept of Liberation in Luke 4:16-22 and Exorcism in the Church: The Nigerian Experience
}

\author{
John Arierhi Ottuh, Ph.D \\ Lecturer at Nehemiah Bible College, Okwokoko, Delta State and Vicar: Winners Baptist Church, \\ P. O. Box 1214, Effurun, Delta State, Nigeria \\ Email: wibachef90@yahoo.com \\ Revd. Gideon 0.Oyibo \\ Department of Theology, Baptist Theological Seminary, Eku, Delta State \\ revgooyibo@gmail.com \\ Dr. Andrew 0. Okoro \\ Department of Religious Management and Cultural Studies, Ambrose Alli University Ekpoma \\ revokoro4gospel@yahoo.com
}

\section{Doi:10.5901/ajis.2015.v4n1p195}

Abstract

This research was conducted to examine the concept of liberation in Luke 4:16-22 against the understanding and practice of exorcism by some Nigerian exorcist and faith-healers. Using the liberation model as a method, the paper used the passage (Luke 4:16-22) as a recipe for exorcist and faith-healers in Nigeria. The study revealed that Jesus' concept of liberation (deliverance) in Luke 4:16-22 was not intended to exert violence on or exploit the victim of demonic oppression or illness. Furthermore, the passage showed a compassionate declaration of God's willingness to liberate or deliver the oppressed from their predicament with the power of the Holy Spirit. As far as liberation and exorcism were concerned, the Church in Nigeria was challenged to rely on the power of the Holy Spirit so as to avoid abuse and embarrassment of victims. The church is also admonished to be concerned and fight for the right and liberation of the oppressed in Nigeria.

Keywords: Concept; Liberation; Exorcism; Church;

\section{Introduction}

The issue of liberation is always a front burner among those who are either under oppression or those suffering under natural circumstances like illness. The people in this category of oppression are willing to go to anywhere where they believe that their problems will be solved. They are some times being exploited by some heartless prophets or pastors with their endless list of items to be bought for the rituals. In most cases the problem gets worst. Not withstanding, there are also genuine servants of God who are compassionate like Jesus and have been given the power of exorcism and faith-healing. Nigeria has experienced both sides of the coins in the issue of false and genuine exorcist and faith-healers. Diara and Onah (2014) observed that the proliferation of churches in Nigeria is a further boost for more emergence of false and genuine exorcist and faith-healer. This is why it has become a source of business enterprise for some people in Nigeria.

The aim of this study therefore, is to use the passage (Luke 4:16-22) as a recipe for exorcist and faith-healers in Nigeria. Using the method of liberation as a model, the paper agues that the physical exertion of force on the victim in the process of exorcism and faith-healing is not found within the understanding of liberation in Luke 4:16-22. Moreover, the exploitation of such victims is not also encouraged in the passage. The liberation method is chosen here because the liberation model tends to use the bible as a basis for the fight for the right of the oppressed. Here the exorcists and faithhealer, including the entire church in Nigeria are being admonished to fight a common cause of delivering people from spiritual and physical oppression with the power of the Holy Spirit. 


\section{Conceptual Clarification}

The American Heritage Dictionary of the English Language (2011) see liberation as the act of liberating or the state of being liberated; the gaining of equal rights or full social or economic opportunities for a particular group; the gaining of protection from abuse or exploitation. Also, the Oxford dictionary (2014) defined liberation as the action of setting someone free from imprisonment, slavery, or oppression.

Another key word in this paper is exorcism. The Dictionary of Unfamiliar Words (2008) defined exorcism as a ritual performed to expel an evil spirit. The term exorcism has been defined as "the binding of evil powers by the triumph of Christ Jesus, through the application of

the power demonstrated by that triumph, in and by his Church (Petitpierre, 1972:16). Also Perry (1996:2) sees exorcism as a deliberate act of binding or releasing, performed on a person who is believed to be possessed by a spirit of evil intent. Adu-Boahen (1999); Vuha (1994:v) also agreed that deliverance, a term which is preferred by neoPentecostals, aims at freeing people from the influence or bondage of Satan and his allied evil spirits, who bring about afflictions, sufferings, bad habits, curses and failure in life. In nut shell the word exorcism is an act of liberation.

\section{The Situation of Exorcism: the Nigerian Church Experience}

One of the contemporary situation in which exorcism can be viewed in Nigeria is the situation of the application of physical violence in the process of exorcism in some Nigerian Churches. One of the passages they refer to for this exercise is Luke 4:16-22. Owoeye, (2012) observing the Nigerian church, states that healing and casting of demons are common among the Pentecostal believers in Nigeria especially among the leaders of Pentecostal Churches of which the practice of healing, casting out of demons, deliverance from 'the power of darkness', and sometimes, from poverty by Pentecostal preachers have become an integral part of Christianity in Nigeria. Ejizu (1991) also pointed out that the church activity in exorcism and faith-healing in Nigeria has become so pronounced for the past thirty years and it is commendable. However, some false teachers and misguided pastors do mess up the concept of exorcism and faith healing. Inordinate proliferation of Churches and over emphasis on exorcism and faith miracles is indeed becoming alarming in Nigeria (Diara and Onah, 2014). It is a common place to see some people who call themselves deliverance pastors in Nigeria. Their major work according to their claim is exorcism but it amazes one to see that they apply some measures of physical force in the process. Some times, broom sticks are used to flog anyone suspected to be a witch or wizard. They apply this because they believe that doing it this way will enable the victim to confess and be set free. Sometimes, innocent children are their victims. Such children are tortured to admit the spirit of witchcraft.

Some of these so called deliverance ministers use whips on people who they suspect to be demon- possessed in order for the demon to live the victim. The degree of flogging depends on how demon infested the person might be. Some others defraud people by charging them for the work of deliverance. The deliverance minister evaluates the victim and charges the victim according to the measures of demons found in the person. Some times, the victims are asked to bring money to purchase items of deliverance. Such items may include olive oil, candles of many colours, special animals like dove, threads, special cloth, etc.

All of these arouse the critical mind of the scholar and the ordinary reader alike. The practice of exerting force on and demanding for money from victims of oppression amount to fraud and falsehood. This constitutes another level of oppression to the victims of these false pastors and prophets. Being that this situation exists in Nigeria, the church and indeed scholars of the bible in Nigeria should use the passage (Luke 4:16-22) and other parallel passages as recipes for exorcist and faith-healers in Nigeria.

\section{Literature Review on Liberation Theology}

\subsection{Liberation Theology}

Liberation Theology, according to Evans (2002) is a theological movement that developed in the Latin America in the 1960s, emphasizing the gospel as a power that liberates oppressed peoples from unjust economic, political and social structure. Furthermore, Evans (2002) states that Liberation Theology is rooted in the special concern the Bible shows for the poor, but it has created controversy by sometimes relying on Marxist-inspired analyses of poverty and oppression. Also, Evans see Liberation Theology as a theology to upholds the rule of Justice (that is giving people what is due them), with Biblical injunctions and as such Liberation Theology could be seen as one of the tools for peace building in the 
affairs of men.

Ukpong (2006) opines that Liberation Theology as a model is a way of exploring the Bible as a resources for the socio-economic and political critique of the status quo, and for the struggle for liberation. Although, Marxist method of Liberation Theology appeals to violence in socio-political and economic restructuring, modern Liberation Theology like that of Gutierrez and others like him appeal to peaceful reformation. This sub-heading therefore shall address the origin of Liberation Theology, Marxism and Liberation Theology, freedom from social, economic, political and spiritual oppression, and Black Liberation Theology: the Third World experience.

\subsection{The Origin of Liberation Theology}

Conn (1998) says that liberation theology originated from Latin America in the late 1960s and that it is largely Roman Catholic in origination. He further states that the orientation of Liberation Theology was a movement that seeks to interpret the Christian faith from the perspective of the few and the oppressed. Skidmore and Smith (1984) agree that the Spanish and Portuguese colonized the Latin Americans and in the process they preached the gospel on the one hand and exploited the wealth of the people on the other hand in the name of the Church and state made one by theology and law. Moreover, according to Skidmore and Smith, the colonial masters subjected the Latin Americans and treated them like slaves in their own native land and meted violence on them and even killed some of them. Carrol (1987) says that the Latin Americans especially some daring priests protested against the oppression and injustice meted on them by the colonial masters and as such some of them were killed but it latter birthed liberation theology movement. One of the renowned Liberation Theologians according to Smith (1991) was Gustavo Gutierrez who published his book titled: A Theology of Liberation in 1971 and this has influenced many liberation theologians over time.

\subsection{Marxism and Liberation Theology}

In the understanding of Kirk (1979) liberation theology seems to agree with the concept of Marxism in the area of social analysis which condemns the oppression and neglect of the poor in the society. He states further that though the Marxist uses Philosophy and political approach in its thoughts, Marxism remains an instrument in the hand of every liberation theologian. He also agrees that there is a dialogue between theology of liberation and Marxism.

Banino (1975) opines that the idea of Marxism which deals with socio-economic and political sphere of man in a total freedom from suffering and poverty gives a great boost to liberation theology when looking at it from a socioeconomic and political point of view. Boff and Boff (1986) state that whatever truth that is found in Marxism which is close to that of Christian faith toward Marxism is no different from its attitude toward any other system of thought. In the opinion of Aman (1984), Marxism, as liberation theologians claim, is simply used as a tool, most embraced as a comprehensive worldview.

Miranda (1974) argues that every liberation theologian in Europe uses the concept of Marxism in one way or the other irrespective of the criticism going on among theologians. Though Marxism is an instrument that can be used by liberation theologians as Assman (1984) observed, it has some limitations and one of such limitation is the use of scientific instruments for reading reality. He observed also, that Marxist's use of scientific means to read reality is imperfect because most of these realities are spiritual in nature and cannot be verified scientifically. In this same understanding Segundo (1979) gives two problems that liberation theologians have with Marxism:

a. Marxist negative view of religion; and

b. Marxist methodological rejection of the relative autonomy of the superstructure.

Due to the above problems, Segundo goes so far as to say that direct collaboration between orthodox Marxist Sociology and Liberation Theology is improbable. Gutierrez (1973) claims that any consideration of Marxism must start from two elemental points: class struggle and naturality. He states further that class struggle is part of human economic, social, political, cultural and religious reality.

\subsection{Freedom from Social, Economic, Political and Spiritual Oppression}

Anorsal (2003) says that throughout the bible, one of God's primary purposes for His people is to free them from physical oppression and hardship and to liberate them from spiritual bondage. To him, one of the dominant themes in the Bible is the theme of liberation and that God was seen in the Old Testament as God of liberation especially that of Israel from Egyptian bondage. Moreover, he states that in the New Testament likewise God is the one who liberates people from 
bondage to sin through Jesus Christ and that Jesus showed in Luke 4:18-19 that these purposes extend to all those who are oppressed, not just those who call on His name. This liberation always comes from God, but He desires to use His people to accomplish these purposes.

Yamgblood (2003) opines that liberation theology is a key theme in the bible which expresses itself in both spiritual and social ramifications of salvation in Christ and that it also addresses issues related to political freedom such as freedom from the institution of slavery, freedom from oaths and obligations, freedom from guilt and punishment, and freedom from sinful, destructive habits. He further clarifies that our freedom is not the ability to do whatever we desire, rather our liberation is from sin, oppression and calamities and our ability to deny ourselves of sinful pleasures and please God.

Smith (1991) agrees with Romero's proclamation of liberation for the masses. Smith buttresses that God's word must be read and preached in such a way that it enlightens social, political and economic realities and that a Christianity which does not address the social, political and economic sphere of the people is not Christianity at all. Brockman (1982) asserts that real liberation theology is that liberation that has, above all, respect for the dignity of human beings, the serving of the common good of the people, and a transcendence that looks before all to God, and from God derives its hope and its force. Scholars such as Beeson and Pearce (1984), Leroux (1982), Lange and Iblacker (1981), Berryman (1984), Montgomery (1982), Quigley (1982), Williams (1985), Bonpane (1985), Cabestrero (1983), Jerez (1984), and Belli (1988) opined that liberation theology is a theology of social, religious, political and economic transformation and that if such transformations take place man will be liberated from all sort of oppression, limitation, and suffering. They agree that this transformation can be enhanced by the academicians in the university and seminary, the Clerics, and laity alike. As a matter of history of the emergence of liberation theology, Skidmore and Smith (1984), Medhust (1984), Bauer (1983), Bouvier (1983) and Vekemans (1976) attest that Christianity arrived Latin America through the Spanish and Portuguese with a mix-bag of exploitation and subjugation by fusing the church and the state. In this same line, Caroll (1987), Richard (1987) and Cabal (1978) note that the oppressive and slavery action milted on the Latin American caused some liberative voices such as Bartolome de las Casas, bishop of Chiapas, Mexico, Diego Medellin, bishop of Santiago, Chile, Authonio de Valdivieso, bishop of Nicaragua, Antonio San Miguel, bishop of La Imperial, Peru, Juan del Valle, bishop of Popaya, Luis Beltan, Antonio de Vieyra, and Antonio Montesinos to emerge against the oppressive governmental policies, domination and exploitation milted on the Latin Americans. Thus, these voicified resistance and revolutions brought about political and economic independence to the Latin Americans later on.

Lacy (1985) sees liberation theology as a theology that does not restrict itself to the personal or spiritual realms of life but also a theology that engages with economic, political and cultural matters. Lacy further states that liberations theology must deal not only with the concerns, questions and issues of the discipline of theology traditionally conceived, but also understand the workings of the larger social world.

Considering the employment of social science in doing liberation theology, Boff and Boff (1987) and Bonino (1975) argue that liberation theology does not employ any and every social science perspective especially, the structuralfunctionalist framework of social analysis which create different world between the poor and the rich. Instead, the above scholars, see liberation theologians as standing with "dialectical" or historico-structural analysis and that this analysis views poverty as a collective and conflictive result of oppression which can only be overcome through the establishment of an alternative social system through social-structural transformation. They explain further that liberation theologians use neo-Marxist analysis simply because, as a tool, it seems to them to explain their social world best. Boff (1987), explains that though Marxism fights against impoverishing it should not be venerated above the Bible and that liberation theology uses Marxism purely as an instrument.

Gutierrez (1983) understands that liberation theology must be done to address the situation of those who have been dehumanized in the society through poverty, oppression and domination. Gutierrez (1987) further exerts that liberation theology should seek to answer the following questions:

i. How are we to talk about the God who is revealed as love in a situation characterized by poverty and oppression?

ii. How are we to proclaim the God of life to men and women who die prematurely and unjustly?

iii. How are we to acknowledge that God makes us a free gift of love and justice when we have before us the sufferings of the innocent?

iv. What words are we to use in talking to those who are not even regarded as persons that they are daughters and sons of God?

Gutierrez also attempted to answer the above questions when he says that God is the God of true love, justice and equity. In this same vain, Gutierrrez argues that, to know Yahweh, which in Biblical language is equivalent to saying to 
love Yahweh, it is to establish just relationship among men, it is to recognize the rights of the poor and that the God of biblical revelation is known through inter-human justice. Hinkelammert (1986) contends that, God's will and human liberation coincide completely, because human liberation is the will of God.

\section{The Concept of Liberation in Luke 4:16-22}

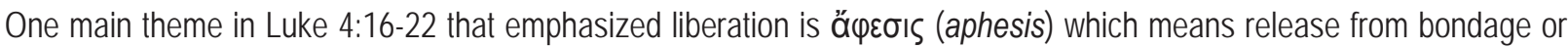
imprisonment, forgiveness or pardon or remission of the penalty. Another theme that emphasized liberation in the passage is ióopa (iaomai), meaning to cure, heal, to make whole, to free from errors and sins, or to bring about (one's) salvation. In the New Testament, the Greek word for salvation as mentioned above is $\sigma \omega{ }^{\prime} \eta p^{\prime} \alpha$ and it connotes the idea of abstract and material liberation or deliverance and from its etymology $\sigma \omega \dot{\zeta} \zeta \omega$ (sozo), it means to save, heal, deliver, preserve, do well, and to be whole. When the noun owtnpía (sōtēria) is used, it conveys the understanding of defense,

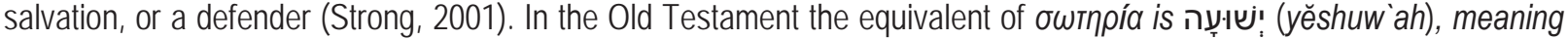
Yaweh saves, delivers, rescues or helps. This word is used in the Old Testament to refer to the deliverance of the Israelites from the Egyptians (Ex 14:13) and of deliverance generally from evil or danger. In the New Testament (in Hebrews 2:3) it is specially used with reference to the great deliverance from the guilt and the pollution of sin wrought out by Jesus Christ (Eston, 2011).

Abogurin (2000) states that the inescapable realities of life in the world at the time of Luke was the massiveness of suffering, persecution, deprivation, inequality, slave labour, bondage, poverty, diseases and so on despite the deep religious atmosphere that pervaded the whole of the world. Luke's message according to Abogurin is the main aspiration for the fullness of life which Christ gives to man. Furthermore, he states that in Luke 4:14-30, Jesus declared His Messianic mission of which He was to save the soul of man as well as the physical predicament or situation of man which is realized in amnesty, salvation, healing, restoration and liberation from socio-economic and political oppression. This mission in Abogurin's opinion is summarized in Luke 4:18-19, thus;

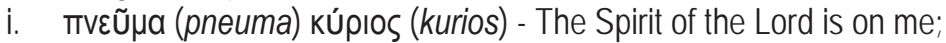

ii. He has xpíw (chrio) anointed me;

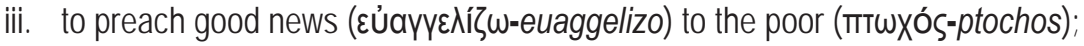

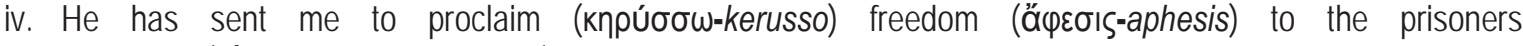

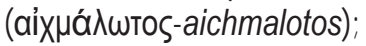

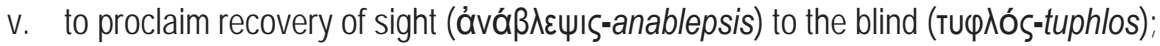

vi. to proclaim release to the oppressed (Epaúw-thrauo); and

vii. to proclaim the year of the Lord's Favour.

To Abogurin, this quotation which was taken from Isaiah 61:1-2, encompasses the theology of liberation from socio-economic and political injustice as well as the soul of man from condemnation. Tutu (1986) asserts that the concept of liberation is not only found in the Old Testament Exodus experience but also in the New Testament. He says that Jesus is a liberator hence He is called the Messiah. He further states that the concept of liberation in Luke 4: 16-22 is total and comprehensive. He further submits that the understanding of liberation from the bible is an inspiration for the move of liberation from socio-economic and political oppression. Banana (1990) agrees with Tutu that the concept of liberation from Luke 4:16-22 can be used to formulate an economic and political theology of liberation. To them the pericope justifies a fight for the liberation from economic, social and political injustice. In the same vain, Nolan (1988) opines that the statement of Jesus in Luke 4:16-22 was a re-echo of Isaiah 52:7 to describe His prophetic message and

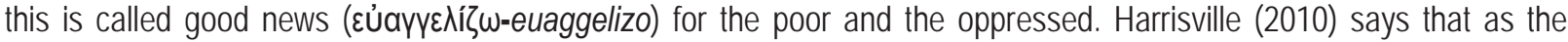
prophetic passage stated, someone had been anointed to proclaim the gospel (good news) and the irony is that Jesus is the one anointed at his baptism at which the Spirit descended upon him in bodily form, according to Luke. But only Luke and the reader know that at this point. As with all Epiphany texts, this one holds hidden promise for the future. Moreover, Harrisville (2010) asserts that the good news in Isaiah refers to the restoration of Israel after the exile; the "poor" receive good news, not cash, because in Isaiah they are the afflicted and the oppressed in general, not merely the penniless; likewise, captives are not convicted criminals but those unjustly imprisoned; and the sightless will see again because all these promises will be fulfilled in the telling of the story of Jesus as he releases people from demon possession and death, spiritual and physical blindness. To Harrisville (2010) all these activities are tied together in the "year of the Lord's favour which refers to the Jubilee Year as proclaimed in Leviticus 25:10 and if so, it is another ironic utterance for the Jubilee Year was to have occurred every fifty years in Israel when the land was to lay fallow, all debts forgiven, and all slaves freed; however, Jeremiah 34:14 suggests that the Jubilee Year had not been followed and that when King 
Zedekiah did try to institute the practice, it was circumvented by the people hence confusion abounds as to whether or not the practice was ever truly instituted and yet, the Jubilee Year has influenced such practices as the statute of limitations in our day. He states further that such pronouncements of authoritative largesse by kings and rulers like Jesus did, have been a commonplace among the ancients and as such the Caesars were often portrayed as grand liberators and generous benefactors but for Jesus to read this message from Isaiah and proclaim its fulfillment is therefore an indictment of all politicians who claim to bring release and freedom but true freedom does not consist in money and possessions or in the ability to do as one pleases. Harrisville citing American as example of state that are used to the idea of freedom as license to do as one wishes; Jesus, however, understands freedom differently to mean a release from captivity to death, the will of others, and the will of the self and Jesus can be seen as one who preached the freedom from slavery to God's will and service to the neighbor (Luke 22:24-27). Harrisville sees God as a one who never leaves people where he finds them for a change in condition always accompanies an encounter with the divine and such radical change is what Jesus proclaims and will perform. Jesus does not merely affirm the condition of his children. He is about the reversal of fortunes that results not just in change in one's environmental state, but in the person itself. For Harrisville (2010) this is not the change that happens with the turnover in governmental administrations because the change Jesus does is real change in the spirit and life of the person who hears this good news and whose life is never the same afterward and whether the Jubilee Year may or may not have been practiced in ancient Israel, but Jesus' announcement does not come simply as an injunction upon imperfect people but as words with power, which affects the change proclaimed for the change which Jesus talked about is not a concept or an idea, it is a person; Jesus is the change and therefore, any definition of release, sight, gospel, or change must be taken from his actions and his words.

In regard to Luke 4:16-22 as good news to the poor, Brueggemann (1978) says that good news gives hope for the future, energizes and encourages the hearer and the receiver. On this same note Stegemann (1984) and Schottroff (1986) add that good news implies the announcement of the will of God for the good of the people who have been denied the good things of live and the neglected in the society.

\section{Concept of Liberation in Luke 4:16-22: Implication for the Nigerian Church}

\subsection{Liberation from Captivity}

There are barriers to man's living life the way he wants. These barriers constitute captivity. These barriers that constitute captivity to man could be political, economical, ecological, medical, social or spiritual. Captivity denies man access to his fullness of life. Man's captivity can be so strong on him in such a way that he cannot help himself out hence Jesus came to save man from captivity of any kind.

\subsection{Compassion for the Oppressed}

Jesus' address was born on compassion for the oppressed. In Israel, it was common to see the less privileged being oppressed by those in high position and wealth. The earth is the place where the physical Church dwells and as such she must make the world a better place to live. Every human created by God has the right to live life to its fullest without being molested by fellow humans. The church should be ready to take side with the oppressed and fight for their rights. Jesus' action in the passage was that of compassion for those that are physically and spiritually oppressed.

\subsection{Liberation from Economic oppression}

Jesus' response to social issues deepens His concern for the poor, the oppressed, widows, orphans, the ill, senior citizens, children and those with disabilities (Isaak, 2006). This social gospel was an unmistakable feature of Jesus' Ministry and it is clear from the verses he quoted from Isaiah when he introduces His ministry to his home town (Ibid). Jesus expresses this concern for poverty alleviation in his message of liberation saying: "the Spirit of the Lord is upon me, because He has anointed me to preach good news to the poor." It is Jesus' opinion that the deprived person in the society who has been denied access to the good things of life be given access to live happily like any other happy person in the society. The things that make an individual poor in the society should be squarely addressed to enable the poor person gain access to available resources like any other person in the society. This was what the early church community practiced in (Acts 4:32-37). The lot of the poor was addressed by physical provision. The main needs of the modern man include: food, shelter, good health, employment, clothing, mobility, education, family and fellowship. It is Jesus' desire 
that man enjoys all of these in life. Poverty with its concomitant effects of alienation, marginalization and dependency poses a serious challenge to the mission of the church in Nigeria.

Poverty embraces many things and it could be described as a condition whereby the victim is alienated from access to the resources that would enable him or her live a full human life in the society of homo- sapiens. Such resources which the poor person lacks may be physical, social, material, spiritual or cultural and are often expressed in terms of the basic necessities of life. A poor person is a victim of such alienation, one who lacks access to such resources and who thereby lives below the subsistence level. Being that poverty alienates people from resources that would lead to the realization of their full humanity, it dehumanizes and depersonalizes people and is to that extent contrary to the message of the gospel and the Christian spirit (Ukpong, 1995).

Both in the Old Testament and New Testament, the poor as distinguished from poverty are object of love and attention. One purpose for the legislation about the sabbatical year in the Old Testament was to enable the poor among the people to eat freely of the fruit of the fallow land (Ex. 23:12). In the beatitudes of the New Testament, the poor are among those to count themselves blessed participants in the kingdom that Jesus came to inaugurate (Matt. 5:3, Luke 6:20); they were also the object of Jesus' Mission (Luke 4:18). In the past, according to Ukpong (1995), in theological discourse, the presence of the poor and of poverty in the society were taken for granted as a social anomaly but did not form the focus of attention. It was thought sufficient to treat the poor with palliatives like material relief and economic and without investigating the course of poverty and seeking for ways to remove them. Today however, theological discourse has moved beyond this to not only questioning the foundations of poverty but also promoting action in solidarity with the poor in order to remove the courses of poverty. This is seen to be in consonance with the example of Jesus who identified with the needy and the poor and acted in solidarity with them during his entire earthly ministry. If Jesus identified Himself with the poor and needy in the society, and if in his ministry, they were the object of His attention, it therefore means that it is the will of God to alleviate the poverty situation of man and make man gain access to the good things of life. This lesson applies to Nigerian situation today of which the verse majority of the people in the area are denied access to the resources that would have bettered their life situation. Jesus' attitude towards the poor in Luke 4:1622 is a theological anchor for our political, traditional leaders as well as religious leaders to be proactive in the alleviation of poverty in the Nigeria.

\subsection{Oppression is Offensive to God and Man}

To oppress (Katadunasteuo) means to exercise power over the weak or powerless (Vine, 1999). How do we prove in this portion of the text that oppression is offensive to God and man? Jesus in the text announces His mission to destroy oppression, for He says: "He has sent me to proclaim freedom for the prisoners and recovery of sight for the blind, to release the oppressed" (Luke 4:18b). Here Luke shows Jesus affirming the value of several other groups that were denied full acceptance in the society of his days (Isaak, 2006). These oppressed persons include: women, children, Samaritans, Gentiles, Tax Collectors, Sinners, Orphans and the disabled. If oppression was good to God, Jesus would not have spoken against it. Therefore, Jesus speaking against oppression depicts the indignation of God against the oppressor. In the Septuagint according to Ukpong (2006), the word mTwxó (ptochos) which has its Hebrew equivalent as לT. (dal-weak, lowly, or poor) refers to physical weakness whereby a person cannot challenge his or her opponent because he does not have the power or authority to defend himself when attacked. Generally, the oppressed persons in the society are those who are wrongfully dispossessed of their rights. Since God is the author of these rights, to deprive a person of them is to act against God. Hence when an oppressed person cries out at the injustice milted on him or her, he or she is at the same time pleading God's case who acts in defense for the oppressed (Ps. 9:18; 12:5, 35:10).

Following Jesus' example, the contemporary church and her leaders should at all times speak the truth as it is informed by our faith. We are called to the prophetic ministry that is rooted in local congregations at grass-roots communities struggling with major social issues. Being engaged in such a ministry will result in conflict, mutual reprimands and bitter debates as we seek to resolve differences or to bring inconsistencies to light. The point is that change is some times a slow matter, like giving birth. The new life is there, democracy is there, a new spirit of racial coexistence is there, gender awareness and promotion of it are there, but all are being born in much pain. Doing truth, practicing our theology, implementing justice, showing loving kindness and walking with God are never simple matters. We are engaged in a struggle that is ongoing. If God hates oppression, fellow humans should also hate oppression and live together as co-imago dei. This is therefore, a challenge to the Federal Government and the multinationals operating in the Niger Delta region of Nigeria to peacefully co-exist with the fellow humans in Niger Delta. Our leaders should wear a human face that is devoid of oppression so as to share the dividend of the natural resources equitably to the owners. 


\subsection{Captivity Connotes Physical and Spiritual Maladies}

The idea of Captivity is found in the Bible in both the physical sense and the metaphorical sense. In the physical dimension of captivity as presented in the text manifests itself in ill-health, material poverty, psychological affliction (the broken hearted) and environmental disorder. In the Bible, the Israelites were held as captives in Egypt and Babylon though they later deported them, they did not escape suffering. Jeremiah (20:2, 32:2-3, 37:11-21), John the Baptist (Matt. 14:3), Jesus (Matt. 27:2), the Apostles (Acts 12:4, 16:23) and the servant in Matthew 18:30 were all examples of physical captivity. In the Metaphorical or Spiritual sense death helds humanity captive (Rom.7:6), sin holds the sinner captive (John 8:34) and the human and even cosmic condition before justification from God is a condition of captivity - Rom. 7:14, 23 (Rom, 1973).

All these situations must be seen as comprising the condition of captivity that is envisaged in the text. In a sense they constitute a situation of oppression and poverty in the sense that their victims are held banned to their course. The lesson that can be drawn here for the Church in Nigeria situation as at today is the captivity caused by economic and social deprivation and demonic forces. Some times the captivity could be health situation. This deprive man from enjoying life to its fullest. This is why liberation from illness is important for man.

\subsection{A Theological Manifesto}

Jesus' reading of the text demonstrates God' immanent as well as His eschatological plan for man's rest and fulfillment in life. What is a vision? A vision in the physical sense is an imaginary imagery or projection of what a person plans to do in the future. In the context of Luke 4:16-22, Jesus could be seen as a man or a leader with vision because He has a plan to deliver or liberate those in any form of captivity from their immediate as well as their future situations. All these are within the plan of God for man (Jere.29:11). God wants man to live a purposeful life, that is, a life with a well defined purpose. Jesus read the text with a purpose and not just for the fun of rabbinic display of intelligence.

This is a challenge to the contemporary pastors (priests) and all those who proclaimed the Gospel of Jesus Christ to have the plight and the liberation of the oppressed the topmost in their agenda of preaching the Gospel. Some are preaching it to exploit the poor and even make them poorer. The Gospel is Good News and as a Good News it must affect man both spiritually and physically as embedded in the vision, purpose, and will of God for man.

\section{Conclusion}

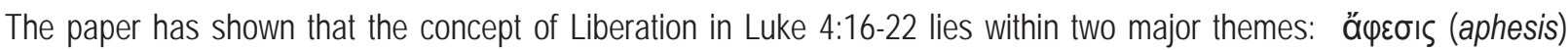
meaning release from bondage or imprisonment, forgiveness or pardon or remission of the penalty; iáouaı (iaomai), meaning to cure, heal, to make whole, to free from errors and sins, or to bring about (one's) salvation; and $\sigma \omega t \eta \rho i ́ a$ meaning salvation. All of these give the idea of physical and spiritual salvation (liberation).

The Nigerian church has been challenged to understand that deliverance is not just about violent exorcism but physical and spiritual steps that are taken by the church in order to make man live life to its fullest. One of such steps to be taken is to take side with the oppressed like Jesus did and fight for the right of the oppressed in church community and society at large.

\section{References}

Abogunrin,S.O.(2000a).Situation Theology as a Recipe for African Theological Exploration. African Journal of Biblical Studies 54:1-18.

Abogurin, S.O. (2000b). The Lucan View of Jesus Christ as the Saviour of the World from the African Perspective. Journal of Religious Thought (55) 1:27-43.

Adu-Boahen, S. (1999). Deliverance from Demons: Teachings on Deliverance with Numerous Practical Testimonies of Deliverance from Demons. Kumasi: U. G. C. Publishing House.

Aman, K. (1984).Marxism(s) in Liberation Theology. Cross Currents,34: 427-438.

American Heritage ${ }^{\circledR}$ Dictionary of the English Language (2011), Fifth Edition. Houghton Mifflin Harcourt Publishing Company. http://www.thefreedictionary.com/liberation. Retrieved January 16, 2015.

Assman, H. (1974). Medellin: La Desilusion que nos Hiz, adurair. In: Cristianismo and Sociedad 12:137-143.

Assmann, H. (1976). Theology for a Nomad Church. Marryknoll: Orbis Book,107pp.

Banana, C. (1980).Good News to the Poor. In: Your Kingdom Come. Geneva: World Council of Churches. 27-31.

Banana, C. (1990). The Gospel According to the Ghetto. Gweru Zimbabwe: Mambo Press, 68pp.

Bauer, A. J. (1983).The Church in the Economy of Spanish America. Hispanic American Historical Review, 6:707-733. 
Beeson, T. and Pearce, J. (1984), A Vision of Hope: The Churches and Change in Latin America. Philadelphia: Fortress Press, 65pp.

Belli, H. (1988). Liberation Theology and Latin American Revolutions. The Politics of Latin American Liberation Theology. Washington D. C: The Washington Institute Press, 621pp.

Berryman, P. (1979).What Happened at Puebla. In: Levine, D. H.(ed.) Churches and Politics in Latin America, Calif: Sage Publications, 9-15.

Bock, D.L. (1992). Luke, Gospel of. In: Green, J.B.; McKnight, S. and Marshall, I.H.(eds.) Dictionary of Jesus and the Gospels. Downer Grove: InterVarsity Press, 495-510.

Boff, L. and Boff, G. (1987).Salvation and Liberation. In:Search of a Balance Between Faith and Politics. New York: Orbis Books,21-26.

Bonino, J. (1975).Doing Theology in a Revolutionary Situation. Maryknoll, New York: Orbis Press, 112pp.

Bonino, J. (1975).Doing Theology in Revolutionary Situation. New York: Orbis Press, 68pp.

Bonpane, B. (1985). Guerrillas of Peace: Liberation Theology and the Central American Revolution. Boston: South End Press,153pp.

Bouvier, V. M. (1983). Alliance or Compliance: Implication of the Chilean Experience for the Catholic Church in Latin America. Syracuse, New York: Maxwell School of Citizenship and Public Affairs Publications, Syracus University,67pp.

Brockman, J. R. (1982). The Word Remains: A Life of Oscar Romero. Maryknoll, New York: Orbis Books,56pp.

Brueggemann, W.(1978). The Prophetic Imagination. Minneapolis: Fortress, 46pp.

Cabal, H. L. (1978). The Revolution of the Latin American Church. Norman: University of Oklahoma Press, 267pp.

Cabestrero, T. (1983). Ministers of God, Ministers of the People: Testimonies of Faith from Nicaragum. Maryknoll, New York: Orbis Books,67pp.

Caroll, D. (1987) What is Liberation Theology? Dublin: The Mercier Press, 53pp.

Conn. M. H. (1998).Liberation Theology. In: Ferguson, S. B. (ed.) The Challenging of Black Theology in South Africa. Atlanta: John Knox, 387-391.

Diara, Benjamin C.D. and Onah, Nkechinyere G.(2014). The Phenomenal Growth of Pentecostalism in the Contemporary Nigerian Society: A Challenge to Mainline Churches. Mediterranean Journal of Social Sciences 5 (6): 395-402.

Dictionary of Unfamiliar Words (2008). Diagram Group Copyright (C) 2008 by Diagram Visual Information Limited. http://www.thefreedictionary.com/exorcism. Retrieved January 15, 2015.

Ejizu, Christopher I. (1991). Cosmological Perspective on Exorcism and Prayer-healing in Contemporary Nigeria. Mission Studies Viii-2 (16): 165-176.

Evans, C.A.(2000).Messianism. In: Evans, C.A. and Porter, S.E. (eds.) Dictionary of New Testament Background. Downers Groves, Illinois: Inter-Varsity Press, 698-707.

Evans, C.S. (2002). Pocket Dictionary of Apologetics and Philosophy of Religion. Downers Grove: Inter-Varsity Press, 125pp.

Gutierrez, G. (1987). Job: God-Talk and the Suffering of the Innocent. Maryknoll, New York: Orbis Books,203pp.

Gutierrez, G. (1988).A Theology of Liberation. Maryknoll, New York: Orbis Books,79pp.

Gutierrez, G.(1983). The Power of the Poor in History. Maryknoll, New York: Orbis Books,69pp.

Harrisville, R. (2010).Commentary on Luke 4:14-21.www.drbilllong.com/ Lectionary/ Luke4.html. Retrieved on August 23, 2011.

Hinkelammert, F. (1986).The Ideological Weapons of Death: A Theological Critique of Capitalism. Maryknoll, New York: Orbis Books,75pp.

Jerez, C. (1984). The Church and the Nicaraguan Revolution. Cross Currents 34: 5-42.

Kirk, J. A. (1979).Liberation Theology: An Evangelical View from the Third World. London: Marshall, Morgan \& Scott,85pp.

Kirk, J. A. (1980), Theology Encounters Revolution. Leicester, England: Marshall, Morgan \& Scott,59pp.

Lacy, H. (1985).Liberation: Philosophy and Politics. Cross Currents, 35:219-241.

Lange, M. and Iblacker, R. (1981). Witness of Hope: The Persecution of Christians in Latin America. New York: Orbis Books,78pp.

Lernoux, P. (1979). The Long Path to Puebla. Maryknoll, New York: Orbis Books,69pp.

Lockyer, H. (1986).Nelson's Illustrated Bible Dictionary. New York: Thomas Nelson Publishers,3927pp.

Miranda, J. (1974).Marx and the Marxists. Maryknoll, New York: Orbis Books,69pp.

Montgomery, T. S. (1982).Cross and Rifle: Revolution and the Church in El Salvador and Nicaragua.Journal of International Affairs 36:209-221.

Nolan, A. (1988). God in South Africa: The Challenge of the Gospel. Grand Rapids: Eerdmans and Mambo Press, 7-30.

Nolan, A. (1988). God in South Africa: The Challenge of the Gospel. Grand Rapids: Eerdmans and Mambo Press, 7-30.

Owoeye, S.A. (2012). Healing in some Pentecostal Churches in South-Western Nigeria. European Scientific Journal 8 (30): $95-113$.

Oxford Dictionary (2014). http://www.oxforddictionaries.com/definition/english/liberation. Retrieved January 15, 2015.

Peech, M. (1965). Hydrogen ion Activity. In: Black, C A. (ed) Methods of Soil Analysis 2:914- 926.

Perry, M. ed. (1996). Deliverance: Psychic Disturbances and Occult Involvement, 1987, Second Edition. London: SPCK.

Petitpierre, Dom R. ed. (1972). Exorcism: The Findings of a Commission Convened by the Bishop of Exeter. London: SPCK.

Reasoner, M. (1993). Romans, Letter to the. In: Hawthorne, G.F.; Martin, R.P. and Reid, D.G.(eds.) Dictionary of Paul and His Letters. Downer Groves: InterVarsity Press, 838- 855.

Richard, P. (1987). Death of Christiandoms, Birth of the Church. New York: Orbis Books, 49pp.

Richards, P. W. (1952). The Tropical Rain Forest. Cambridge:University Press,67pp.

Schottroff, L. and Stegemann, W. (1986). Jesus and the Hope of the Poor. Maryknoll: Orbis,64pp.

Schottroff, L. and Stegemann, W. (1986). Jesus and the Hope of the Poor. Maryknoll: Orbis,64pp.

Segundo, J. (1973). Theology for Artisans of a New Humanity, Maryknoll: Orbis Book, 41pp. 
Segundo, J. (1976). Liberation of Theology.Maryknoll, New York: Orbis Book, 49pp.

Segundo, J. L. (1979). Capital Versus Socialism: Crux Theology. In: Gibellini, R. (ed). Frontiers of Theology in Latin America. Maryknoll, New York: Orbis Books,13-17.

Smith, C. (1991). The Emergence of Liberation Theology, Chicago: The University of Chicago press,49pp.

Smith, C. (2000). The Ultimate Guide to the Bible Uhrichsville: Barbour Publishing, Inc,440pp.

Stegemann, W.(1984). The Gospel and the Poor. Minneapolis: Fortress,45pp.

Tutu, D. (1986). Liberation as a Theological Theme: the Story of Exodus 1. Hope and Suffering. Grand Rapids: William B. Eerdmans, 4961.

Ukpong, J. S. (1995b). The Poor and the Mission of the Church in Africa. New Testament Essays. Lagos. Campbell Publishers, $31-43$.

Ukpong, J.S. (1995a). Inculturation and Evangelization: Biblical Foundation. In: Ukpong, J.S.(ed.) New Testament Essays Lagos: Campbell Publishers, 22-30.

Ukpong, J.S. (2006). African Biblical Interpretation: A Reader (unpblished). Uyo: University of Uyo, 275pp.

Vekemans, R. E. (1976). Teologia de la Liberaciony Christianos Por el Socialismo. Bogota, Colombia: CEDIAL.

Vuha, Aaron K.(1994). The Package: Salvation, Healing and Deliverance. Second Edition. Accra: The Prayer Warriors International.

Williams, P. J. (1985). The Catholic Hierarchy in the Nicaraguan Revolution. Journal of Latin American Studies 17: 341-369.

Youngblood, K. J. (2003). Freedom. In: Brand, C.(ed.) Hosman ISS Bibible Dictionary , 601-602. 